\title{
PARENTING IN CONFLICT - PARENTAL ALIENATION: NETNOGRAPHIC RESEARCH
}

\author{
MAGDALENA ROSZAK ${ }^{1}$ \\ 1 The Maria Grzegorzewska University, Social Pedagogy Department, Szczęśliwicka 40, 02-353 \\ Warszawa, Poland. ORCID: 0000-0001-6678-6702,Email: magdallenaroszak@gmail.com
}

\begin{abstract}
Parental alienation is a phenomenon that appears after the divorce or break-up in a situation, where there is high conflict between the separating parents accompanying the termination of the relationship. It includes actions intentionally taken by one of the sides, who is seeking to distort the relationship between the child and the other parent. As a result of the alienation, the child starts to excessively prefer the custodial parent and intensively reject the non-custodial parent. The discussion concerning parental alienation was initiated by Richard Gardner, a psychiatrist, who introduced the idea of PAS 'parental alienation syndrome'. His concept was widely commented by its supporters as well as by sceptics and opponents, as a result of which its modified version, PA 'parental alienation', was developed. Published research concerning the subject can be found in English-language scientific articles as early as in 1998. However, in Polish academic literature parental alienation is almost non-existent. The objective of this article is to open a discussion on this subject. Apart from theoretical analysis of the phenomenon, the narratives of parents who believe to experience PA were analysed. The analysis regarded aspects such as: definition, characteristics and sources of parental alienation. The article analyses also actions, which are the alienated parents' reactions to PA. The performed analysis was of netnographic nature. KEYWORDS: parental alienation syndrome, parental alienation, divorce
\end{abstract}




\title{
INTRODUCTION
}

\begin{abstract}
divorce strongly influences the individuals, that participate in it; it rates second Aon the Social Readjustment Rating Scale by T. H. Holmes and R. H. Rahe among the most stressful life events (after the death of a spouse). It constitutes a series of changes modifying the life of the member of a family unit. Source literature describes it as a negative and undesired event (Tyszka 2002; Graniewska 2004; Balcerzak-Paradowska 1999). According to the authors, it causes disorganization in life, negatively affects psychological, physical, financial and social spheres of adults' and children's lives. However, the most difficult situations are cases, where the divorce is connected with a high conflict between the spouses. Sometimes the antagonisms between the parents do not stop even after the break-up or divorce, because shared custody and brining up children are the area, where the conflicts are constantly revived. Lack of trust and anger between the parents - fighting for custody over children before family courts, are elements which additionally cause the problems to escalate. An extreme example of such antagonism is the phenomenon of parental alienation.
\end{abstract}

\section{PARENTAL ALIENATION - THEORETICAL ANALYSIS}

Parental alienation (PA) is a controversial subject in the scientific world. The discussion between researchers concerns the very fact of existence of PA as well as its theoretical and scientific grounds, tools for diagnosis and treatment methods in case it is identified. The first person who opened a large scale discussion on parental alienation was a psychiatrist, Richard Gardner, who described the concept of PAS (parental alienation syndrome) (Gardner 1998, 2001, 2002, 2004). The author assumed, that PAS is a 'disorder that arises primarily in the context of child custody disputes. Its primary manifestation is the child's campaign of denigration against a parent, a campaign that has no justification. It is caused by a combination of a programming (brainwashing) parent's indoctrinations and the child's own contributions to the vilification of the targeted parent' (Gardner 1998). R. Gardner distinguished symptoms shown by children in regard to the non-custodial parent (guardian). These include:

(1) A Campaign of Denigration

(2) Weak, Frivolous, or Absurd Rationalizations for the Depreciation

(3) Lack of Ambivalence - unambiguous hostility towards the non-custodial parent

(4) The "Independent-Thinker" Phenomenon, where the child denies the influence of the alienation parent, he/she is convinced of expressing their own opinions

(5) Absence of Guilt Over Cruelty to and/or Exploitation of the Alienated Parent

(6) Reflexive Support for the Alienating Parent in Parental Conflict 
(7) Presence of Borrowed Scenarios regarding past events, that is the child copies the alienating parent's argumentation

(8) Spread of the Animosity to the Extended Family and Friends of the Alienated Parent (Gardner 1992).

Gardner distinguished three forms of alienation: mild, moderate and severe. He created their characteristics and described legal and therapeutic solutions for each case (Gardner 2001, 2002, 2004).

Gardner's concept caused a wide discussion in the scientific community. It was claimed to:

(a) not have scientific value: lack of precision of basic terms; no validation in specialist literature; lack of full dichotomy of Gardner's division - lack of evidence that would made it comprehensive and the importance of the symptoms is imprecise; PAS is not included in International Classification of Diseases;

(b) disregard (covering up) for incestuous actions;

(c) Gardner's antifeminism (sexism) in using the term 'mother' and main guardian interchangeably, therefore suggesting that only mothers alienate their children;

(d) one-sidedness in presenting the parents: excessive simplifying in pointing at the custodial parent as the only person responsible for an improper relationship with the other parent and assigning personality disorders to the alienating parent (Czeredecka 2018).

Alicja Czeredecka (2018) widely addressed the claims toward PAS concept indicating at the same time the fact, that many of them could be dismissed. The author emphasized, among others, that colloquial language used by Gardner does not discredit the concept itself and it only indicates, that it requires further development. She listed many examples from psychological literature confirming the phenomena observed by the psychiatrist. The author also pointed out, that the existence of other characteristic symptoms, that were not included in PAS, has not been proven so far. Additionally, including PA (parental alienation - a modification of PAS) in ICD-11 dismissed another one of the claims. However, the author emphasized also, that symptoms described by Gardner were included only on the level of behaviour and they did not refer to their underlying mechanisms. She also drew attention to the validity of the claim of one-sidedness in presenting the parents. According to Czeredecka (2018), practice and research show, that in case of a high conflict between the parents, that results in alienation, both parents show disorders and parenting mistakes. In this respect, important differences were not found between the sexes. Moreover, Gardner did not include unconscious reasons for custodial parents' actions, the systems of defence mechanisms, that they developed and altruistic aspects of their motivation (serving a higher - according to the alienating parent - just purpose for the good of the child).

Therefore, the concept of PAS required modifications, which in turn led to the con- 
cept of parental alienation (PA). Douglas Darnall and Wiliam Bernet contributed to its development. P. Darnall defined PA one of the parents conducting conscious actions, which result in anger, reluctance and opposing to court decisions, consciously or unconsciously denigrating the other parent in the eyes of the child and interfering with their relation with the intention of breaking it up (Czeredecka 2018:50 as cited in: Darnall 2008). The author pointed out, that the problem concerns the parents. Meanwhile, W. Bernet emphasized the significance of disorders visible in the child. According to him, parental alienation is a mental state, where the child usually involved in the legal conflict between the parents related to their divorce or separation strongly allies with the alienating parent and rejects the relationship with the other parent without justification. PA is characterized by unnormal, non-adaptive behaviour caused by a false opinion on the alienated parent (Czeredecka 2018:51, as cited in: Lorandor and others 2013:5).

The concept of PA differs in some aspects from PAS. In PA the outside source in the form of the alienating parent and a set of dysfunctions in the relationship is considered to be the point of gravity and not as in PAS: the child's own participation in the occurrence of the phenomenon. What is more, in PA alienating activity is examined on both sides of the conflict, and not only in reference to the custodial parent (Czeredecka 2018). Parental alienation in a modified form is described as a process and the changes that occur within in as dynamic. The alienators are not only parents, but they can also be the child's grandparents, relatives, new partners (Darnall 2008).

Polish scientific literature lacks research and publications devoted to parental alienation (Czeredecka 2018). However, there is an increase in scientific articles published on the subject in the United States and Great Britain. Aforementioned Wiliam Bernet and Douglas Darnell as well as Ronald Rohner, Nilgun Gregory and Amy Baker all have made important contributions to the development of the discussion on the analysed subject.

The authors point out practical aspects of parental alienation related to legislation, diagnosis and therapy. They observed two objectively identified and quantitatively measured traits visible in children experiencing parental alienation: rejecting the non-custodial parent (Huff, Anderson, Adamsons \& Tambling 2017) and lack of ambivalence in idealizing the custodial parent (the alienating parent) and devaluation of the non-custodial parent (Kelly \& Johnston 2001; Lee \& Olesen 2001; Ellis 2007; Bernet, Gregory, Rohner, \& Reay 2018). Analysing the second indicator, the authors point out, that children usually see both parents in an ambivalent manner, they see their strengths and their weaknesses. A high conflict between the parents makes it difficult for them to maintain the same level of affection for both parents. Children resolve this cognitive dissonance with a dividing mechanism - entering an intense relationship with one parent and rejecting the other. The child's behaviour results from a false belief, that the rejected parent is bad, dangerous, undeserving of love. As a consequence, children have a particularly positive image of the custodial parent and an extremely negative image of the non-custodial parent (Bernet, Gregory, Rohner, \& Reay 2020).

Parental alienation is described as a complex form of violence in the family. It is a result of force, control and generating fear used by the custodial guardian (Harman 
and others 2018). Alienating behaviours have been documented in scientific research. Denigration of the other parent, accusing him/her of not loving the child, controlling the child, forcing an alliance on the child, discussing grown up issues with the child, limiting contact with the other parent which infringes court decisions on parent's time and communication with the child and even false accusations of sexual abuse (Baker 2005; Baker \& Darnall 2006; Harman et al. 2018).

The conducted research did not give an unequivocal answer to the question which of the sexes demonstrates a larger tendency for alienating behaviours. Fathers as well as mothers are guilty of that type of parental violence (Harman, Leder-Elder, \& Biringen 2016; Balmer et al. 2017). However, as indicated by Harman and others (2016), women and men, that are alienators are viewed differently by third parties: fathers definitely more negatively than mothers. The authors see the influence of these discrepancies on the functioning of social institutions, such as family court, law enforcement or psychological pedagogical clinics. Moreover, these institutions have important impact on the discussed issue contributing to the development and prevention of parental alienation.

The authors emphasize, that alienating a child has consequences to his/her development and functioning. Long-lasting and unresolved conflict between the parents results in, among others, post-traumatic stress, disturbances in psychological and social functioning, low self-esteem, substance abuse, depression, difficulty in building relationships, fears and phobias (Harman, Bernet, \& Harman 2019). Moreover, children are not the only ones considered to be victims, but also the parents, who suffer from: depression, fear, social isolation, emotional difficulties (Balmer, Matthewson, \& Haines 2017; Harman, Bernet, \& Harman 2019), and a high suicide rate (Balmer, Matthewson, \& Haines 2018).

An important moment in the development of research and in strengthening PA in science was introducing the terms of: parental alienation and parental estrangement into International Classification of Diseases in 2018. It allowed for official use of the term of parental alienation in scientific publications. However, as A. Czeredecka (2018) notes, even though ICD-11 recognised the phenomenon, the discussion on scientific value of PA was not closed. Meanwhile, the need for deeper analysis of the phenomenon of parental alienation, standardisation of methods of diagnosis, longitudinal study and development of legal support and therapeutic system are emphasized.

\section{PARENTAL ALIENATION IN POLAND}

In Poland, every year more than 60 thousand marriages end in divorce, in this group around 40 thousand are families with children (Central Statistical Office 2019). The scale of break-ups of non-marital cohabitation, where there are children, is not known (it is not included in statistical data). However, regardless of whether the relationship was a marriage or non-marital cohabitation, many people break-up in conflict, that the children are involved in. How many of them experience parental alienation? In the United States it is estimated, that around 1\% of all children are victims of PA (Bernet 2010; Warshak 2015). However, other research indicates, that there are many more, 
that is even 29\% of all children from divorced parents (Hands \& Warshak 2011). Polish statistical data do not include the phenomenon. Expert opinions, psychotherapists' reports or stories of alienated parents indicate, that parental alienation is strongly present in Poland. It takes on different forms: from organizing the child's free time in a way, that meeting with the other parent collides with fulfilling the needs, pleasures or responsibilities of the child; refusing to give the child to meet with the other parent; unfounded accusations of physical, psychological violence, addictions or even sexual molestation of the child (Czeredecka 2018) and in extreme cases parental child abduction and multiannually, completely preventing the child from seeing the other parent. The motives for alienating parents' actions are usually: revenge, the need for control, financial matters, demonstrating the superiority of their parenting competence, self-presentation in an environment and fear of being abandoned by their child (Czeredecka 2018).

The phenomenon of parental alienation still was not widely discussed in Polish scientific literature. There is a lack of research and practical solutions in form of diagnosis, therapies and legislative aspects. The few considerations appear mainly in the fields of law and psychology, pedagogy does not address the issue.

Patriarchal system, which is dominant in Poland, glorifies the significance of the mother in raising and taking care of children (Hryciuk \& Korolczuk 2012), which collides with the change in modern paternity, negating the patriarchal patterns. More and more often men are increasingly present in the sphere of raising and taking care of children. They also more and more often demand their parental rights in case of a separation or divorce. Bogusława Budrowska (2008) talked about gradual redefinition of the father figure and calls this qualitatively new fatherhood paternity. Modern, manly parenthood is based on a strong, emotionally deep connection with the child, built from the earliest moments of life (Kubicki 2009). Such a model of fatherhood has educational competences similar to the mother's (Sikorska 2009). However, in the society and judiciary still dominates a belief, that mothers are more predisposed to take care of children. Because of that stereotype, it seems logical, that after the divorce it is the mother who is awarded custody. Analysing court decisions on parental authority and custody over minor children in years 1980 - 2018, we can see some changes occurring in this sphere. They are shown in the Table below. 
Table 1. Parental authority and custody over minor children awarded after divorce according to court decisions in Poland in years 1980-2018

\begin{tabular}{c|c|c|c|c}
\hline Year & \multicolumn{4}{|c}{ Parental custody after divorce was awarded to (in percentage): } \\
\hline & $\begin{array}{c}\text { The } \\
\text { Mother }\end{array}$ & $\begin{array}{c}\text { The } \\
\text { Father }\end{array}$ & $\begin{array}{c}\text { Together to the Mother and } \\
\text { the Father }\end{array}$ & $\begin{array}{c}\text { Separately to the Mother } \\
\text { and the Father }\end{array}$ \\
\hline $\mathbf{1 9 8 0}$ & 77,4 & 2,6 & 17,7 & 1,2 \\
\hline $\mathbf{1 9 9 0}$ & 72,7 & 3,4 & 21,6 & 1,3 \\
\hline $\mathbf{2 0 0 0}$ & 65,0 & 3,6 & 29,2 & 1,1 \\
\hline $\mathbf{2 0 1 0}$ & 57,3 & 4,2 & 36,5 & 0,9 \\
\hline $\mathbf{2 0 1 7}$ & 41,0 & 3,8 & 53,5 & 0,7 \\
\hline $\mathbf{2 0 1 8}$ & 36,8 & 3,5 & 57,9 & 0,7 \\
\hline
\end{tabular}

Source: own work based on Statistical Yearbook 2019, Central Statistical Office

The above table shows a quantitative increase in parental authority and custody from a formal viewpoint, awarded to the mother and the father together after the divorce. At the same time, formally there are less and less cases where custody is awarded solely to the mother. Nonetheless, the area of fathers having full custody does not significantly change. However, by comparing these data with the number of children aged $0-17$ raised in families (from $22 \%$ of children raised by one of the parents $20 \%$ was raised exclusively by the mother and only $2 \%$ were raised by their fathers (Central Statistical Office 2015) it can be assumed, that after the divorce children typically live with their mothers (custodial parent) and meet with their fathers (non-custodial parent) in a place determined by the court and in an extent agreed upon by the parents. Therefore, since after the divorce children usually live with their mothers, it can be assumed that in Poland statistically they will be alienating parents more often than fathers.

\section{METHOD, OBJECTIVE, DESCRIPTION OF THE GROUP}

The following study of the phenomenon of parental alienation was conducted with the use of qualitative research paradigm. The leading method was netnographic. Netnography is a method of research by performing participant observation, used to work in the virtual world. It uses forms of mediated communication through the computer as a source of data in order to reach ethnographic understanding and to show the chosen cultural and social phenomena (Kozinets 2012:93). The method was created by Robert V. Kozinets, who dates back its beginning to 1996. However, the concept of online social life itself comes from Howard Rheingold (Kozinets 2012). Netnography began in the area of marketing and consumer studies and was then adapted to, among others, cultural, social, legal, communication studies and anthropology (Kozinets 2012). Netnography is a qualitative and interpretative research methodology, which adapts traditional ethnographic techniques, among others, observation and interviews for researching online communities and cultures. Furthermore, unlike ethnography, where it is impossible, it allows to have an insight view into archive data, which significantly broadens the analyzed perspective, giving us the possibility to observe even years 
of the changing process. Netnographic research develops accordingly to the steps of ethnographic research: planning, entering the area, gathering data and interpreting it, while maintaining appropriate ethical standards, and then presenting the research. The basic matter of interest of researchers who use netnography are online communities, which are groups of entities that share the same goal, hobby or interest, interacting with each other on the Internet. Such a community creates content, develops relationships and forms a community culture based on its unique norms. One example of such a community are parents experiencing the phenomenon of parental alienation, who create groups on Facebook. The netnographic method used in this study allowed to present and explain the phenomenon of parental alienation existing in Polish families through the examined community.

The researcher in order to see and understand the mechanism and the process of parental alienation joined a Facebook group - Kocham, szanuję, nie alienuję. Dziecko (przed, $w$ trakcie, po) rozstaniu rodziców (eng. Love, respect, don't alienate. The child (before, during after) the break-up of parents) on $31^{\text {st }}$ May 2019. The group brings together non-custodial parents, who, in their opinion, are experiencing parental alienation, their partners and people interested in the subject.

Archived and published posts were observed and commented by the researcher. Having obtained the consent of the administrator and other members of the group they were analysed together with the published comments. Collecting the materials took from June 2019 to May 2020. In June 2020 the researcher analysed the collected narratives using manual analysis of qualitative data, that is manual techniques of coding, categorising and classifying (Kozinets 2012:182) and quantitative analysis of discourse (Gruber 2011).

The objective of research in this article is to show the phenomenon of parental alienation through the perception of non-custodial parents, who believe to be experiencing it.

The researcher formulated the following research areas:

1. What is parental alienation and what does it mean according to the subjects?

2. What are the reasons for parental alienation?

3. What actions are taken by members of the group to reduce or eliminate PA?

The group was started on $21^{\text {st }}$ March 2015 on Facebook social platform, as a place for discussions, exchange of views and experiences regarding divorce, conflicts between parents, activity of Family Courts and shared custody. The leading thought developed in the group is: 'the child has a right to have both parents!'

'Kocham, szanuje, nie alientuje...' has the status of a private group (only members can publish and see other posts; in order to become a member, one must obtain the consent of the administrator). It gathers 3070 people (information as of 20th May 2020), amongst who there are observers, commentators and people, who publish posts. Around $60 \%$ of group members are men. 


\section{PARENTAL ALIENATION IN THE NARRATIVES OF NON-CUSTODIAL PARENTS}

In 'Kocham, szanuję, nie alienuję...' group, every day there is a discussion regarding the phenomena related to parental alienation. Analysed posts include narratives describing experiences and views on subjects relating to PA; and apart from that films, auditions, photographs and pictures and information about events related to the subject (among others, scientific conferences, lectures, congresses, meetings, happenings, manifestations).

Most popular subjects discussed in the group:

1. Violence of Parental Alienation (46 posts written from the moment of creating the group included a \# marked with this topic, it does not mean, that there weren't more posts published about this subject, data as at 20 $0^{\text {th }}$ May 2020)

2. Family Court and Family Law (39)

3. Parental Child Abduction (29)

4. Shared Custody (28)

5. Rights of Children (27)

\section{PAS (26)}

Moreover, discussions were held on subjects such as: The Hague Convention, parental conflicts, divorce, parental planning, false accusations, trial, court-appointed family guardians, psychologists.

Parental alienation in the analysed group is experienced directly by the parents (but also guardians - e.g. grandparents) and children, or indirectly observed by the partners of alienated parents. The subjects describe it as a form of violence, which is well-illustrated by what was said by one of the group administrators: "This is violence towards the other parent, but especially towards the child'. And also: 'this monstrous, destructive machine which is parental alienation, it only becomes bigger and makes more and more damage, because there is no one, who would impose any sort of restrictions on that machine, and even if there are restrictions, you can't enforce them, even worse, there is silent permission for breaking these restrictions." Such a standpoint - PA is violence, is present in the narratives of many of the research subjects and it is confirmed by source literature (Harman, Leder-Elder, \& Biringen 2016; Balmer \& others 2017; Harman et al. 2018).

From the point of view of the analysed subject matter, what is important is the size and diffusion of the phenomenon. Members of the group who were asked within the forum: 'How many people (children, parents, their relatives) in Poland are affected by Violence of Parental Alienation?' commonly responded that the number is very high. Among the comments, there were answers such as: 'an immensity'; 'a bunch'; 'many'; 'too many';'95\%, 90-95\% that is the truth, everybody has some one, but they don't always know about it'; 'I would even say, that there is no one who doesn't have around them a person related to $P A$ '. This shows that the subjects consider parental alienation a common 
phenomenon. It is not surprising considering their personal involvement in the analysed subject matter. However, it is difficult to address this assessment in a scientific manner due to the lack of statistical data on the subject.

Group members were asked about the extent of alienation, that they have experienced themselves, in a post of the following content: 'How many of you has an isolated child and since when?' 234 comments were published under the post (information as of $20^{\text {th }}$ May 2020), that showed many alienated guardians: fathers, mothers, grandmothers and grandfathers. They determined the time with no contact with the child in years (the longest time of isolation was 15 years of no contact, the shortest was 4 months, most commonly it was $2-3$ years without the possibility to meet with the child/children).

Alienating behaviours experienced by the analysed parents and guardians refer most of all to isolation from the child. The scale of the phenomenon is laid on a certain, noticeable axis. On one of its ends there is organising the child's time by the custodial parent in a way, that it collides with the time when meeting with the other parent was scheduled (extra-curricular classes, tutoring, interest groups, attractions, doctor appointments). The next point on the axis is failure to carry out court orders regarding the time of meetings and no contact between the parent and the child, which is accompanied by the custodial parent changing their phone number or blocking calls or even parental child abduction. The last point is a complete lack of meetings, which the analysed subjects described as lasting for years.

Parental child abductions are often described by the subjects. They involve the custodial parent moving together with the child/children, without the consent of the other parent and without informing the non-custodial parent about that fact and about their future place of residence. One of the fathers described it as follows... 'I come to visit my boy and the child is gone... and I don't know where he is, the phones are dead (...) and me, the father, well, I supposedly have rights to the child, but they exist only on paper...' In their statements, the subjects often emphasize, that current legal arrangements in Poland do not prevent parental child abductions and even treat them as legal. It is showed by one of the narratives... 'the mother performed a classic and legal in Poland parental child abduction...' The subjects' stories of what they directly experienced told in the group together with published fragments of films, documentaries and press articles depict parental child abductions.

Another aspect of parental alienation described by the subject is not giving and even blocking access to information about health, education and future of the child. One of the fathers described it as follows... 'for the last 2 years a complete lock on information about the child and none, not even one decision was made together. I send e-mails with questions about health issues and life decisions...ostracism...' The subjects describe it as a complex phenomenon, in which teachers or headmasters of educational establishments are often involved. Referring to the position of the Minister of Justice, one of group members wrote...'school and pre-school are obliged to make the child's documentation available to the parent, even when one parent's parental authority regarding co-decision-making on important matters relating to the child is limited...'. However, according to the subjects that is often not respected and they have to apply for infor- 
mation through legal channels.

Lack of information form the custodial parent spreads also into the area of the child's important life events. The subjects indicate, that they are not being informed about dates of ceremonies (e.g. Christening, First Communion, child's birthday party, child's participation in contests and competitions, shows and sport events) or they receive that information from third parties. It makes it difficult to participate in them and excludes non-custodial parents from their children's important life events.

One of the most burdening forms of parental alienation, next to not having contact with the child, are false accusations towards the non-custodial parent regarding domestic abuse, addictions, sexually abusing the child, mental diseases, bullying and stalking. The phenomenon is described several times in the analysed group. The alienated parents present a similar pattern: the custodial parent files a complaint with the court regarding domestic abuse, sexual abuse of the child etc. The accusations turn out to be groundless. However, slowness of Polish courts makes the process very long. As written by one of the persons...'Us, for 3 years under art. 207 Criminal Code [abuse] - we never leave the court, same false accusations, no evidence'.

"Educating" the child, programming, manipulating, brain washing are terms used in discussions describing further alienating behaviours. They include ...'teaching the child what he/she should say to the next 'specialist'...' especially when the subject is the other parent and the child's relationship with him/her. However, they also include badmouthing the other parent to the child, lying about them and talking about the conflict between the parents, in which the child should not be involved. Next to the narratives of parents experiencing such behaviours, films and articles in Polish and English on the subject are often published in group.

Summarising the result of seeking an answer to the question: 'what is and what does parental alienation mean in the opinion of the subjects', it is violence towards the child and the other parent. It usually involves isolating the son/daughter from their non-custodial parent and not informing the parent about the child's health, education, interests and future. Relatively less frequently the subjects wrote about false accusations and 'programming' of the child as well as negative reactions to the non-custodial parent; however, those aspects of parental alienation were also present in the narratives. Considering that these are topics of a 'delicate' nature, it seems necessary to continue the thread in individual interviews. It is especially indicated by the fact, that it was this aspect of child's behaviour, that confirms the existence of parental alienation.

Analysing the posts published by members of the group in terms of seeking the answer to what are the reasons for parental alienation, the researcher reached the following conclusions. The subjects see the reason for PA in a few sources: the alienating parent himself/herself, family law, the functioning of Family Courts.

Alienating parents are described by the subjects only pejoratively. Members of the group use (mostly in reference to mothers) terms like: 'owner', 'madka' (a commonly known mocking form of the Polish word mother - matka), 'alienator', 'torturer', 'criminal', 'the executioner of her child's mental health'. They often accuse them of having mental diseases, emotional disorders, psychopathy, borderline personality disorder, 
narcissistic personality disorder. There are also suggestions like: 'The alienator should be sent to a psychiatric/psychological assessment and then to long-lasting treatment and therapy'. What is more, the alienating parent is accused of having economical motivations. As said by one of the subjects: 'sadly, the main motivation is money instead of the child's wellbeing, the conflict is purely economical, the mother does not agree to shared custody, because she wouldn't get alimony and social benefits.'

The actions of an alienating parent, according to the subjects, are supported by family law, which does not include equal rights for the parents in the situation where they are both awarded custody over the child. As written by one of the subjects: 'awarding full custody together to both parents is a paradox in my view, the above slogan is FICTION'. Apart from that, Polish law is also accused of making parental child abductions legal.

The great majority of posts published in the group regards the actions of Family Court. It is described by the subjects as an institution that supports parental alienation, that divides parents into 'dominant' (custodial) and 'visiting' (non-custodial), where the main task of the latter is to pay alimony. As described by one of the fathers: 'there is so much said about the equality of partners (dividing responsibilities) in a relationship (marriage). Funny how it is all forgotten in the court room. Suddenly, it turns out, that the child needs the other parent (usually the father) only to a residual extent'.

Accusations present in the narratives of the examined persons, regarding Family Courts, are mainly:

- No reaction and silent permission for the violence of parental alienation (being pro violence);

- Idleness and lack of protection for the child victim;

- Resistance to deciding on shared custody, where 'the children would have two equally valuable parents';

- Corruption 'among legal corporations and court expert witnesses',

- Low level of competence and ethics among court expert witnesses giving opinions on family situations;

- 'Impunity of family court judges and practically no independent, social control over the functioning of family courts';

- Feminization, bias and treating fathers as second category parents.

The last issue analysed in the study was answering the question: What actions to eliminate PA or its results are proposed by members of the group? Analysis of published narratives indicated few categories of answers.

1. Offensive actions. Active counteracting and fighting PA by:

Trials in Family Court regarding the extension of custody,

Reporting the custodial parent's failure to fulfil obligations set by the court to 
the law enforcement or the court;

Spreading awareness about parental alienation (organizing manifestations, happenings, scientific conferences, publications, writing petitions to the government and state legislative authorities),

Fighting for legal presumption of shared custody,

Acting on the verge of legality or against the law.

2. Reactive actions. Reacting to PA in a balanced manner, clarifying without attacking the other side. As said by one of the subjects 'actually, the only strategy is to nurture the relationship with the child. You don't have power over what the child's mother is doing and saying. It is often horribly frustrating, that you have to explain and untwist the manipulations from her side, especially after longer absences'

3. Defensive actions. Focusing on building a relationship with the child, not referencing to the alienating person. 'The children will get older, such nonsense about their father coming from their mother will be shrugged off, what counts are meetings, to laugh together, tell fun stories, not talking about their mother!'

Shared custody is a commonly appearing topic in the narratives of the members of the group. It is viewed as a remedy for parental alienation. In the words of one of the members of the group 'this should be the norm, for the vast majority of children!' Its benefits for the development of the child and valuable means of its implementation are often mentioned. However, in most narratives of members of the group there is a visible and emphasized lack of shared custody within Polish realities of after-divorce functioning of families and the consequences of that state. The perspective is shown through other countries (e.g. Sweden, France or Germany) where shared custody is the standard solution, where the mother and the father both have the child, who has equal rights to both of his/her parents.

\section{CONCLUSIONS}

Parental alienation, after many years of discussion currently has got the status of a scientifically proven phenomenon, registered in international classification of diseases, ICD-11. Over the last decade, increasingly numerous research and articles on the subject occurred in Great Britain, the United States, Italy and Spain, where an example, among others, could be the articles of the leading researcher in the field, Wiliam Bernet. However, despite strong interest in the subject of parental alienation, it still needs deep analysis, standardisation of methods of diagnosis, longitudinal study and development of legal support and therapeutic system.

The phenomenon of parental alienation is little represented in Polish scientific community. There is a lack of studies, research, publications in domestic scientific literature. The few considerations on the subject appear in the fields of law and psychology, pedagogy does not address the issue. In order to fill that void, there is a need 
for quantitative and qualitative research showing the extent of the phenomenon and its impact on the family with particular regard to its impact on the functioning of children. There is a necessity for scientific discussion on the subject. It is particularly needed in the situation, where more and more Polish families are broken, because of divorce or separation, at the same time remaining in a long, high conflict, the victim of which is the child.

FUNDING: This research received no external funding.

CONFLICT OF INTEREST: The author declares no conflict of interest.

\section{REFERENCES}

Baker, Amy. 2005. “The long-term effects of parental alienation on adult children: A qualitative research study.” The American Journal of Family Therapy 33:289-302. DOI:10.1080/01926180590962129

Baker, Amy \& Douglas Darnall. 2006. "Behaviours and strategies of parental alienation: A survey of parental experiences.” Journal of Divorce \& Remarriage 45:97124. DOI:10.1300/J087v45n01_06

Balcerzak-Paradowska, Bożena. 1999. Polityka rodzinna. Między dwoma modelami. Warszawa: IPiSS.

Balmer, Sian, Mandy Matthewson, \& Janet Haines. 2017. "Parental alienation: Targeted parent perspective.” Australian Journal of Psychology 70(1): 91-99. DOI: 10.1111/ajpy.12159

Balmer, Sian, Mandy Matthewson, \& Janet Haines. 2018. "Parental alienation: Targeted parent perspective.” Australian Journal of Psychology 70: 91-99. DOI:10.1111/ ajpy. 12159

Bernet, William, Nilgun Gregory, Kathleen Reay, \& Ronald Rohner. 2018. “An objective measure of splitting in parental alienation: The Parental Acceptance-Rejection Questionnaire.” Journal of Forensic Sciences 63:776-783. DOI:10.1111/1556-40 29.13625

Bernet, William, Nilgun Gregory, Ronald Rohner, \& Kathleen Reay. 2020. “Measuring the Difference Between Parental Alienation and Parental Estrangement: The PARQ-Gap.” Journal of Forensic Sciences. DOI: 10.1111/1556-4029.14300.

Budrowska, Bogusława. 2008. „Tacierzyństwo czyli nowy wzór ojcostwa.” Kultura i Społeczeństwo 3:123-151.

Czerederecka, Alicja. 2018. „Izolowanie dziecka od drugiego z rodziców po ich rozstaniu.” Pp. 29-84 in Rodzina w sytuacji okołorozwodowej. Współczesne dylematy psychologiczne i prawne, edited by A. Czerederecka. Kraków: Wydawnictwo IES.

Ellis, Elizabeth. 2007. "A stepwise approach to evaluating children for parental alienation syndrome." Child Custody 4(1-2):55-78. 
Gardner, Richard. 1992. The Parental Alienation Syndrome: Guide for Mental Health Professionals. Cresskill, New Jersey: Creative Therapeutics.

Gardner, Richard. 1998. The Parental Alienation Syndrome: Guide for Mental Health Professionals. Cresskill, New Jersey: Creative Therapeutics.

Gardner, Richard. 2001. “The Parental Alienation Syndrome: Sixteen Years Later.” Forum American Academy of Psychoanalysis 45(1): 10-12.

Gardner, Richard. 2002. "The Empowerment of Children in the Development of the Parental Alienation Syndrome.” The American Journal of Forensic Psychology 20(2):5-26. http://www.rgardner.com/refs/ar14.html

Gardner, Richard. 2004. “Commentary on Kelly and Johnston's 'The Alienated Child: A Reformulation of Parental Alienation Syndrome.” Family Court Review 42(4).

GUS. 2015. Dzieci w Polsce w 2014 roku. Warszawa: Główny Urząd Statystyczny.

GUS. 2019. Rocznik Demograficzny 2019. Warszawa: Główny Urząd Statystyczny.

Graniewska, Danuta. 2004. Sytuacja rodzin i polityka rodzinna w Polsce. Uwarunkowania demograficzne i społeczne. Warszawa: IPiSS.

Gruber, Helmut. 2011. „Analiza komunikacji w nowych mediach.” Pp. 89-119 in Jakościowa analiza dyskursu w naukach społecznych, edited by R. Wodak \& M. Krzyżanowski. Warszawa: Oficyna Wydawnicza Łośgraf.

Harman, Jennifer, Sadie Leder-Elder, \& Zeynep Biringen. 2016. "Prevalence of parental alienation drawn from a representative poll." Children and Youth Services Review 66:62-66. DOI:10.1016/j.childyouth.2016.04.021

Harman Jennifer, William Bernet, \& Joseph Harman. 2019. “Parental Alienation: The Blossoming of a Field of Study.” Current Directions in Psychological Science. DOI: 10.1177/0963721419827271.

Harman, Jennifer, Edward Kruk, \& Denise Hines. 2018. "Parental alienating behaviours: An unacknowledged form of family violence.” Psychological Bulletin 144:1275-1299. DOI:10.1037/bul0000175

Huff, Scott, Shayne Anderson, Adamsons, \& Rachel Tambling. 2017. "Development and validation of a scale to measure children's contact refusal of parents following divorce." The American Journal of Family Therapy 45:66-77. DOI:10.1080/019 26187.2016.1275066

Hryciuk, Renata \& Elżbieta Korolczuk. 2012. Pożegnanie z Matka Polką? Dyskursy, praktyki i reprezentacje macierzyństwa we współczesnej Polsce. Warszawa: Wydawnictwo Uniwersytetu Warszawskiego.

Kelly, Joan \& Janet Johnston. 2001. "The alienated child: a reformulation of parental alienation syndrome.” Family Court Review 39(3):249-66. https://doi. org/10.1111/j.174-1617.2001.tb00609.x

Kubicki, Paweł. 2009. „Przemiany ojcostwa we współczesnej Polsce.” in Być rodzicem we współczesnej Polsce. Nowe wzory w konfrontacji z rzeczywistościq, edited by M. Sikorska. Warszawa: Wydawnictwo Uniwersytetu Warszawskiego.

Lee ,Margaret \& Nancy Olesen. 2001. "Assessing for alienation in child custody and access evaluations." Family Court Review 39(3):282-98. https://doi. org/10.1111/j.174-1617.2001.tb00611.x

Sikorska, Małgorzata. 2009. Nowa matka, nowy ojciec, nowe dziecko. O nowym układzie 
sił w polskich rodzinach. Warszawa: Wydawnictwa Akademickie i Profesjonalne. Tyszka, Zbigniew. 2002. Rodzina we wspótczesnym świecie. Poznań: Wydawnictwo Naukowe UAM.

Walęcka-Matyja, Katarzyna. 2009. Struktura rodziny z zróżnicowanie zachowań społecznych i osobowości młodzieży. Łódź: Wydawnictwo Uniwersytetu Łódzkiego.

\section{BIOGRAPHICAL NOTE}

Magdalena Roszak is a PhD student at the Institute of Education at the Maria Grzegorzewska University. Her research interests oscillate among single parenting, parental alienation and gender studies.

OPEN ACCESS: This article is distributed under the terms of the Creative Commons Attribution Non-commercial License (CC BY-NC 4.0) which permits any non-commercial use, and reproduction in any medium, provided the original author(s) and source are credited.

ARTICLE HISTORY: Received 2020-09-02 / Accepted 2021-04-28 